British water supply if the recent cold weather had caused water to be rationed in some places.

The association's study has in part been occasioned by a resolution passed at last year's annual representative conference. That circumstance is counted as a success for the Medical Campaign against Nuclear Weapons, which now claims 1,400 members, perhaps 2 per cent of registered physicians in Britain. Other professional anti-nuclear groups may follow this example.

Architects for Peace has similarly taken the initiative by asking the professional organization whether architects can ethically help with building missile sites or underground bunkers, while both the physicians and the Nursing Campaign against Nuclear Weapons intend to make fun of the plans worked out by central and local government for dealing with the consequences of a nuclear attack.

Mr Michael Walsh, chairman of the nurses' organization, produced a scathing criticism of the official British policy that medical personnel should be dispersed to rural areas if there should be advance

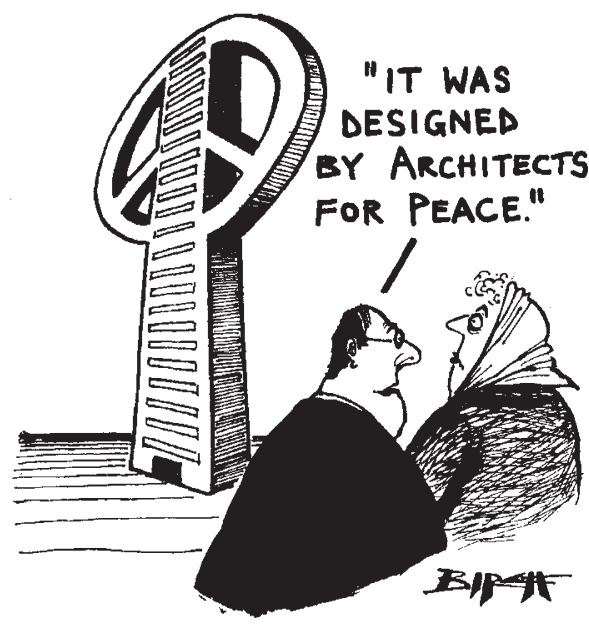

warning of a nuclear attack, and that the urban population should rely on "selfhelp"'. One participant at the conference contributed the intelligence that a local authority plan for dealing with the aftermath of a nuclear attack on the north of England has prudently qualified the advice that the dean of the local medical school should be consulted with the phrase "or his representative".

The surprise of the conference was the declaration by General Michael Harbottle, now secretary-general of the World Disarmament Campaign, that there are now almost enough ex-military men like himself to form an organization called "Generals for Peace"'. More predictable was the steady undertone of criticism of the British and American governments, accused by Ms Norma Turner ("Journalists against Nuclear Extermination") of assailing the media with "anti-Soviet pro-nuclear propaganda". Several speakers considered that the meeting early in June of the NATO council that President Ronald Reagan will attend had been arranged to distract attention from the Second Special Assembly of the United Nations on disarmament, while General Harbottle thought it possible that Queen Elizabeth II's political independence had been compromised by her invitation to the president to dine at Windsor Castle on 10 June.

The conference was attended by 430 people, more than a third of them from the medical professions. About ten per cent of the participants were scientists, among whom Dr Tom Kibble, professor of physics at Imperial College and vice-chairman of "Scientists against Nuclear Arms", raised the provoking (and unanswered) question of how and when to raise with students, "very often the military technicians of tomorrow", the propriety of taking jobs in military research.

\section{Rights on DNA}

\section{Brussels}

A move to widen the scope of the European Human Rights Convention to include the dangers of genetic engineering provides further evidence of the unease which recombinant DNA work still arouses in Europe. A report adopted by the assembly of the Council of Europe in Strasbourg on 26 January included eight recommendations on the legal, ethical and social issues raised by the prospect of interference with human genetic inheritance. The rapporteurs, Lennart Petterson (Social Democrat, Sweden) and Bjorn Elmquist (Liberal, Denmark), based their recommendations on the findings of a public parliamentary hearing last May.

The right to a genetic inheritance free from any form of engineering should be included in the European Human Rights Convention, say the Strasbourg legislators. Exceptions include the treatment of genes to eliminate genetically transmitted diseases but this must only be done with the consent of those concerned or, for children or a fetus, the consent of the parents.

The recommendations also stress the need to monitor the harmonization of safety regulations applied to recombinant DNA research in Europe, and suggest that this should be done by the European Science Foundation. EEC's draft legislation on the registration of DNA research should also be examined to see whether it should be applied throughout Europe. Finally, the Council of Europe proposes to study how microorganisms which have been modified by recombinant DNA techniques can be patented.

Jasper Becker
Chemical warfare

\section{Protest plans}

\section{Washington}

Twenty-five religious, environmental and arms control groups have formed a coalition to lobby against the Reagan Administration's plans to resume the production of chemical weapons after a 13-year moratorium.

The coalition, being organized by the Washington-based Council for a Livable World, was announced last week, just after President Reagan had removed the last remaining legal barrier to resumed production by declaring that the production of nerve gas weapons was "essential" to the national security of the United States.

This in turn coincided with a request from the Reagan Administration for a budget of $\$ 705$ million for chemical warfare activities conducted by the Department of Defense for the 1983 fiscal year, which begins on 1 October. $\$ 77$ million is also being added to the budget for the current year, which will now total $\$ 532$ million - and compares with the $\$ 111$ million being spent only four years ago.

Included in the 1983 request, most of which will be spent on improving defensive equipment and apparatus, is $\$ 30$ million which will be used to produce "binary weapons" at the Pine Bluff Arsenal in Arkansas. Congress has already agreed to spend $\$ 20$ million to build the production facilities, which are now expected to be completed by mid-1983.

According to Defense Secretary Caspar Weinberger, two types of chemical weapons will be produced: $155 \mathrm{~mm}$ artillery shells and Big-Eye bombs. Both will be based on the binary concept, in which two non-lethal chemicals are stored separately.

President Reagan's announcement had been widely expected, following pressure from the US military to replace the existing stockpile of chemical weapons, and widespread claims about Soviet superiority in chemical weapons as well as the alleged use of "yellow rain" in South-East Asia. (Nature 293, 327; 1981).

Two years ago, the Pentagon's Defense Science Board, chaired by Dr John Deutch of the Massachusetts Institute of Technology, recommended a start on the production of binary weapons and that the Department of Defense should prepare for a major increase in its chemical warfare programmes. The department is said to be planning to spend about $\$ 1,400$ million in 1984 , and even more later.

Supporters of the chemical weapons programme argue that it is necessary to persuade the Soviet Union to speed up the chemical disarmament treaty, which the United States and the Soviet Union have been discussing in Geneva since 1975.

In a letter to the leader of the House of Representatives, Mr Tip O'Neill, President Reagan argued that the resumption of production, which had been banned by 